\title{
Plant Age and Growing Season Nutritional Content Relationships of Three Artemisia tridentata Subspecies
}

\author{
Barry L. Perryman, ${ }^{1}$ Teshome Shenkoru, ${ }^{2}$ Leroy B. Bruce, ${ }^{1}$ and Hussein S. Hussein ${ }^{1}$ \\ Authors are ${ }^{1}$ Associate Professors, and ${ }^{2}$ Research Associate, Department of Animal Biotechnology, Mail Stop 202, \\ University of Nevada-Reno, Reno, NV 89557, USA.
}

\begin{abstract}
The effect of plant age on growing season chemical compositions and rumen fermentation characteristics was determined for three subspecies of big sagebrush: basin (Artemisia tridentata [Nutt.] subsp. tridentata), mountain (A. tridentata subsp. vaseyana [Rybd.] Beetle), and Wyoming (A. tridentata subsp. wyomingensis [Beetle and Young]). In vitro dry matter (IVDMD) and organic matter (IVOMD) disappearance, ammonia nitrogen $\left(\mathrm{NH}_{3} \mathrm{~N}\right)$, and volatile fatty acid (VFA) content were determined at the end of two fermentation periods $(24 \mathrm{~h}$ and $48 \mathrm{~h}$ ) by combining rumen inocula with age-classified vegetative samples from each sagebrush subspecies. An additional one-way analysis of variance was performed to investigate potential differences among subspecies in IVDMD, IVOMD, total VFA, and $\mathrm{NH}_{3} \mathrm{~N}$ following a 48-h fermentation period. Crude protein (CP), neutral detergent fiber (NDF), acid detergent fiber (ADF), and acid detergent lignin (ADL) components were also compared among sagebrush subspecies. Age class responses were variable across the spectrum of sagebrush subspecies and response variables. Where plant age effects were indicated, the small numeric differences probably have little biological or ecological significance. Mountain sagebrush was lower in IVOMD and total VFA concentrations $(P<0.0001)$ than basin and Wyoming. $\mathrm{NH}_{3} \mathrm{~N}$ concentration and $\mathrm{CP}$ were higher $(P<0.0001)$ in basin sagebrush than the other two subspecies, while Wyoming sagebrush was higher in NDF, ADF, and ADL than basin and mountain subspecies $(P<0.0001)$. $\mathrm{NH}_{3} \mathrm{~N}$ concentration for all three subspecies was lower than the minimum level $\left(20 \mathrm{mg} \cdot 100 \mathrm{~mL}{ }^{-1}\right)$ required for uninhibited rumen activity. Overall, this research questions the contention that older sagebrush plants offer less nutritional value than younger ones, at least for growing season conditions. The results also provide information that can be utilized in designing supplementation strategies for domestic animals on diets with characteristically high utilization of big sagebrush.
\end{abstract}

\section{Resumen}

El efecto de la edad de la planta sobre la composición química durante el crecimiento estacional, y las características de fermentación en el rumen se determinaron para tres subespecies de "big sagebrush": basin (Artemisia tridentata [Nutt.] sbsp. tridentata), mountain (A. tridentata sbsp. vaseyana [Rybd.] Beetle), y Wyoming (A. tridentata sbsp. wyomingensis [Beetle and Young]). Digestibilidad in vitro de la materia seca (IVDMD) y digestibilidad in vitro de la materia orgánica (IVOMD), así como el contenido de nitrógeno amoniacal $\left(\mathrm{NH}_{3} \mathrm{~N}\right)$ y ácidos grasos volátiles (VFA) se determinaron al final de dos periodos de fermentación (24 y 48 h) por medio de la combinación de fluido ruminal con muestras vegetativas clasificadas por edad de cada una de las subespecies de sagebrush. Se realizó un ANOVA adicional para investigar posibles diferencias entre subespecies en IVDMD, IVOMD, total VFA y $\mathrm{NH}_{3} \mathrm{~N}$ después de un período de fermentación de 48 horas. Los componentes de proteína cruda $(\mathrm{CP})$, fibra neutra detergente (FDN), fibra ácido detergente (ADF) y de lignina ácido detergente (ADL) se compararon también entre las subespecies de sagebrush. Las categorías basadas en edad fueron las respuestas de las variables en todos los rangos de las subespecies de tridentata y las variables de respuesta. En donde se especificó el efecto de la edad de planta, las pequeñas diferencias numéricas probablemente tuvieron poca importancia biológica o ecológica. La subespecie de "mountain sagebrush" presentó los valores más bajos de IVOMD y las concentraciones totales de VFA $(P<0.0001)$ que la subespecie basin y Wyoming. Las concentraciones de $\mathrm{NH}_{3} \mathrm{~N}$ y contenidos de $\mathrm{CP}$ fueron mayores $(P<0.0001)$ en basin sagebrush que en las otras dos subespecies, mientras que Wyoming sagebrush fue mayor en NDF, ADF y ADL que las otras dos subespecies $(P<0.0001)$. Las concentraciones de $\mathrm{NH}_{3} \mathrm{~N}$ para las tres subespecies fueron inferiores al nivel mínimo $\left(20 \mathrm{mg} \cdot 100 \mathrm{~mL}{ }^{-1}\right)$ que son necesarios para la actividad de los microorganismos del rumen. En general, esta investigación pone en duda la afirmación de que las plantas más viejas de sagebrush proporcionan un valor nutricional menor que las más jóvenes, al menos durante la época de crecimiento. Estos resultados proporcionan información que también puede utilizarse en el diseño de programas de estrategias de suplementacion para los animales domésticos con dietas que se caracterizan en una gran utilización de "big sagebrush."

Key Words: annual growth-rings, Artemisia tridentata, in vitro fermentation, nutritional content, sagebrush

\section{INTRODUCTION}

Research was funded in part by the Nevada Agricultural Experiment Station and the Wyoming Abandoned Coal Mined-Lands Research Program at University of Wyoming. Support was administered by the Wyoming Department of Environmental Quality from funds returned to Wyoming from the Office Surface Mining of the US Department of the Interior.

Correspondence: Barry L. Perryman, Dept of Animal Biotechnology, Mail Stop 202, University of Nevada-Reno, Reno, NV 89557, USA. Email: bperryman@cabnr.unr.edu

Manuscript received 17 June 2009; manuscript accepted 29 August 2010.
Big sagebrush subspecies, basin (Artemisia tridentata subsp. tridentata Nutt.), mountain (A. tridentata subsp. vaseyana [Rybd.] Beetle), and Wyoming (A. tridentata subsp. wyomingensis [Beetle and Young]), dominate more than 40 million hectares of North American rangelands (Miller et al. 1994; Pieper 1994). Big sagebrush has a wide ecological amplitude 
and occupies a diversity of habitats (Beetle 1960), playing a crucial role in providing habitat for both wild and domestic animals. Previous research has investigated nutritional content of sagebrush using point-in-time sampling designs (Tueller 1979; Welch and McArthur 1979). Seasonal nutritional content variation has also been documented (Welch 1989; Riggs et al. 1996). Welch and McArthur (1979) determined that mid-winter crude protein $(\mathrm{CP})$ content is under genetic control, and some accessions develop higher protein content than others. In vitro digestibility studies by Welch and Pederson (1981) and Striby et al. (1987) showed three sagebrush subspecies had higher digestibility values than many other shrub species.

There has been speculation and conjecture that younger big sagebrush plants are preferred over older plants as a forage source for both wild and domestic animals. However, Montana Department of Fish, Wildlife, and Parks (1991) found no differences in levels of protein between young and old sagebrush plants. Wambolt (2004) concluded there was no meaningful difference in $\mathrm{CP}$ or acid detergent fiber (ADF) content between young and mature age classes of three big sagebrush taxa. Wambolt (2004) used qualitative age class designations (young and mature) as treatments. To date, no study has investigated the effect of multiple discreet, plant age categories on nutrient content and fermentation characteristics of big sagebrush during the summer season. Dziba et al. (2007) suggested that livestock can be trained to consume sagebrush during the summer. This project examined the relationship between plant age and nutritional content and fermentation characteristics during the summer. Specific objectives were 1) determine if nutrient content and fermentation characteristics of the three subspecies of big sagebrush were related to plant age; and 2) determine if there were differences in nutrient content among subspecies.

\section{METHODS}

\section{Experimental Design}

Two separate assessments were performed. In the first, each sagebrush subspecies was analyzed as a separate experiment in a two-way analysis of variance. Treatments were arranged in a factorial design that included two in vitro fermentation times $(24 \mathrm{~h}$ and $48 \mathrm{~h})$ and a variable set of age classes for each subspecies. After age determinations were completed, individual plant forage samples from individual stands were pooled into the three regional categories (replications) and further pooled into categorical age classes. Wyoming sagebrush collections yielded six age classes: 1-10 yr (I); 11-20 (II); 2130 (III); 31-40 (IV); 41-50 (V); > 50 (VI). Basin sagebrush collections provided four classes: 1-10 yr (I); 11-20 (II); 21-30 (III); 31-40 (VI). There were seven classes for mountain sagebrush: 1-10 yr (I); 11-20 (II); 21-30 (III); 31-40 (IV); 41-50 (V); 51-60 (VI); > 60 (VII). Response variables included in vitro dry matter disappearance (IVDMD) and in vitro organic matter disappearance (IVOMD). After the IVDMD was performed, the resulting supernatant was analyzed for ammonia nitrogen $\left(\mathrm{NH}_{3} \mathrm{~N}\right)$, total volatile fatty acid (VFA), and the component VFA content, including acetate, propionate, isobutyrate, butyrate, isovalerate, and valerate.
The second assessment was a one-way analysis of variance among subspecies and was conducted using only a 48-h in vitro fermentation time. This analysis included IVDMD, IVOMD, $\mathrm{NH}_{3} \mathrm{~N}$, total VFA, dry matter (DM), ADF, acid detergent lignin (ADL), neutral detergent fiber (NDF), and $\mathrm{CP}$ as variables of interest. All means comparisons were performed using least significant difference (Steel et al. 1996). Data were analyzed with JMP Statistical Analysis Software version 7.0.2 (SAS 2008) and differences determined at $P<0.05$ for all analyses.

\section{Field Methods}

Big sagebrush stands having similar soil characteristics, topography, and minimal herbivory disturbance were selected for this study. Sites were selected to minimize microsite effects that increase or decrease supplemental moisture conditions, thereby minimizing potential variations in nutritional content (Bonham et al. 1991). Stem sections of subspecies wyomingensis were collected from three stands in northeast Wyoming near Rochelle; three stands in the South Fork of the Powder River watershed, northwest of Casper in central Wyoming; and three stands in southwest Wyoming near Pinedale. Stem sections for subspecies tridentata were collected from three stands near Pinedale; three stands from Worland, on the west slope of the Bighorn Mountains; and three stands near Farson, in southwest Wyoming. Stem sections for subspecies vaseyana were collected from three stands near Pinedale; three stands from Buffalo, on the east slope of the Bighorn Mountains; and three stands from the west of Laramie, near Elk Mountain in south-central Wyoming. The three stands in each regional grouping were located within a $24-\mathrm{km}$ radius. Global positioning coordinates for each stand are published in Perryman and Olson (2000).

Field sampling methods were conducted according to Perryman et al. (2001) and plant age determined after Ferguson (1964) and Perryman et al. (2001). Approximately 3 g (DM basis) of nonwoody biomass was collected from each plant at four random locations in the plant canopy. Nonwoody biomass included ephemeral and permanent leaves, and current year vegetative and reproductive stems. Collection was performed prior to ephemeral leaf abscission. Sampling was conducted during the summer of 1997 (a typical water year; Wyoming Water Resources Data System 2007) during the course of sagebrush demography study (Maier et al. 2001). The rationale for summer sampling is based on recent studies indicating domestic animals can be induced through supplementation to increase sagebrush intake (a sagebrush control measure) during seasons other than the typical winter use season (Dziba et al. 2007). Each substrate sample was allowed to air dry in the lab space at room temperature for 3 mo prior to grinding in order to reduce gaseous escape of volatile compounds that can escape with oven heat.

\section{Laboratory Methods}

Sagebrush samples were ground to a 1-mm sieved particle size, and $0.5 \mathrm{~g}$ of substrate from each subspecies age class was loaded into four separate $50-\mathrm{mL}$ centrifuge tubes, one each for the 24-h and 48-h fermentation time treatments and a corresponding duplicate blank tube. Two mature, rumen fistulated Angus steers were used as rumen fluid donors for in vitro fermentations. Steers were fed an alfalfa-grass ration for 
Table 1. Percent in vitro dry matter disappearance (IVDMD), in vitro organic matter disappearance (IVOMD), individual volatile fatty acid, and ammonia nitrogen $\left(\mathrm{NH}_{3} \mathrm{~N}\right)$ concentration for basin sagebrush main effect means (SE) by age class and fermentation time, for growing season nutritional characteristics in Wyoming, 1998.

\begin{tabular}{|c|c|c|c|c|c|c|c|c|}
\hline & \multicolumn{5}{|c|}{ Age class $^{1}$} & \multicolumn{3}{|c|}{ Time } \\
\hline & I & II & III & IV & SE & 24 & 48 & SE \\
\hline$\%$ IVDMD & 53.7 & 53.1 & 53.0 & 52.5 & 0.34 & $48.9 \mathrm{~b}$ & $57.2 \mathrm{a}$ & 0.24 \\
\hline$\%$ IVOMD & $49.8 a^{2}$ & $48.8 \mathrm{ab}$ & $48.5 \mathrm{~b}$ & $48.1 \mathrm{~b}$ & 0.39 & $44.3 \mathrm{~b}$ & $53.5 \mathrm{a}$ & 0.27 \\
\hline Isobutyrate, molar \% & $0.00 \mathrm{~b}$ & $0.21 \mathrm{~b}$ & $0.23 \mathrm{~b}$ & $2.89 \mathrm{a}$ & 0.08 & 0.73 & 0.93 & 0.06 \\
\hline Valerate, molar \% & $2.85 \mathrm{a}$ & $2.66 \mathrm{a}$ & $2.56 \mathrm{a}$ & $1.82 \mathrm{~b}$ & 0.07 & $2.61 \mathrm{a}$ & $2.32 \mathrm{~b}$ & 0.05 \\
\hline $\mathrm{NH}_{3} \mathrm{~N}, \mathrm{mg} \cdot 100 \mathrm{~mL}^{-1}$ & $18.94 \mathrm{a}$ & $19.12 \mathrm{a}$ & $18.03 \mathrm{ab}$ & $15.82 b$ & 0.83 & $14.89 \mathrm{~b}$ & $21.06 \mathrm{a}$ & 0.59 \\
\hline
\end{tabular}

${ }^{1}$ I includes 1-10 yr; II, 11-20 yr; III, 21-30 yr; IV, 31-40 yr.

${ }^{2}$ Row means with different letters differ at $P<0.05$.

4 wk prior to initiating the in vitro experiment. Rumen fluid was collected from the steers $2 \mathrm{~h}$ postfeeding and strained through four layers of cheese cloth into a prewarmed, insulated thermos and transported to the University of Nevada-Reno nutrition laboratory. Rumen fluid was then mixed with McDougall's buffer (McDougall 1948) on an equal volume basis (with $\mathrm{CO}_{2}$ bubbling), and $30 \mathrm{~mL}$ of the inoculum were added to each centrifuge tube (containing a substrate or a blank). Tubes were flushed with $\mathrm{CO}_{2}$, capped with stoppers equipped with one-way gas release valves, and placed in an incubator/shaker (Innova 4400; New Brunswick Scientific, Edison, NJ) at $39^{\circ} \mathrm{C}$ (Tilley and Terry 1963). At the end of two fermentation periods $(24 \mathrm{~h}$ and $48 \mathrm{~h}$ ), the appropriate tubes were placed in storage at $5^{\circ} \mathrm{C}$ for $2 \mathrm{~h}$ to stop the fermentation process.

Separate air-dried (as described) samples were analyzed for $\mathrm{DM}, \mathrm{ADF}, \mathrm{ADL}, \mathrm{NDF}$, and CP components for the one-way analysis of variance assessment (Jeraci et al. 1988; Association of Official Analytical Chemists 2000). Supernatant digesta samples were filtered through a preweighed Whatman 541 filter paper and washed with $78 \%$ ethanol, and acetone then dried at $105^{\circ} \mathrm{C}$ in a drying oven, weighed and ashed in a muffle furnace at $500^{\circ} \mathrm{C}$, and weighed again to determine organic matter $(\mathrm{OM})$ residue. IVOMD was calculated as follows: $(1-[\{\mathrm{OM}$ residue $-\mathrm{OM}$ blank $\}$ /original $\mathrm{OM}]) \times 100$. A 4-mL aliquot was drawn from each substrate tube and prepared according to Erwin et al. (1961) for short chain fatty acid analysis. VFA concentrations in the supernatant were determined with a gas chromatograph (Varian Model 13800; Varian, Inc, Walnut Creek, CA; equipped with a glass column [180 $\mathrm{cm} \times 4 \mathrm{~mm}$ i.d.] packed with GP $10 \%$ SP$1200 / 1 \% \mathrm{H}_{3} \mathrm{PO} 4$ on $80 / 100$ Chromosorb WAW [Supelco, Bellefonte, PA], with helium used as a carrier gas at a flow rate of $85 \mathrm{~mL} \cdot \mathrm{min}^{-1}$. The oven, injection port, and detector port temperatures were $125^{\circ} \mathrm{C}, 175^{\circ} \mathrm{C}$, and $180^{\circ} \mathrm{C}$, respectively). Ammonia nitrogen content was determined after Chaney and Marbach (1962).

\section{RESULTS}

\section{Basin Sagebrush}

No interactions among age classes and fermentation times were indicated for IVDMD, IVOMD, isobutyrate, valerate, and $\mathrm{NH}_{3} \mathrm{~N}$ (Table 1). There were no differences among age classes for IVDMD. Age class I had significantly higher IVOMD
$(49.8 \%)$ than age classes III $(48.5 \%)$ and IV $(48.1 \% ; P=0.02)$, and no differences were observed among classes II, III, and IV. For isobutyrate, age class IV $(1.69 \mathrm{mM})$ had a higher content than classes I, II, and III $(0.0 \mathrm{mM}, 0.12 \mathrm{mM}$, and $0.15 \mathrm{mM}$, respectively; $P=0.005)$. For valerate, class IV $(1.06 \mathrm{mM})$ had a lower $(P=0.005)$ concentration than classes I $(1.62 \mathrm{mM})$, II $(1.53 \mathrm{mM})$, and III $(1.54 \mathrm{mM})$. The lowest $\mathrm{NH}_{3} \mathrm{~N}$ concentration was also observed in age class IV $\left(15.82 \mathrm{mg} \cdot 100 \mathrm{~mL}^{-1}\right.$; $P=0.028)$. Samples fermented for $48 \mathrm{~h}$ had higher $(P<0.0001)$ IVDMD, IVOMD, and $\mathrm{NH}_{3} \mathrm{~N}$ values than $24-\mathrm{h}$ fermentation times.

Interactions between age class and fermentation time were observed for acetate, propionate, butyrate, isovalerate, and total VFA concentrations (Table 2). Total VFA and acetate concentrations were substantially higher for age class III (70.0 \pm 1.1 and $48.7 \pm 1.6 \mathrm{mM} ; P=0.0001$, respectively) at the 48-h interval than all other intervals and age classes. However, the general trend indicates that by the time plants reached age class IV, VFA concentrations declined to the lowest levels.

\section{Mountain Sagebrush}

No interactions among age classes and times were detected for any parameter (Table 3). Acetate, propionate, butyrate, valerate, isovalerate, and $\mathrm{NH}_{3} \mathrm{~N}$ concentrations were similar $(P<0.5)$ among age classes. Lower IVDMD and IVOMD were observed for age class VII $(46.4 \% P=0.018$ and $42.2 \%$ $P=0.033$, respectively) than any other age class, highlighting a generally lower trend with increasing age. Isobutyrate and total VFA concentrations also decreased with plant age $(P=0.006$ and $P=0.031$, respectively). Concentrations of acetate, propionate, valerate, and total VFA were greater $(P<0.001)$ for the 48-h fermentation period than the 24 -h period.

\section{Wyoming Sagebrush}

No age class by time interactions were observed for IVDMD, IVOMD, butyrate, valerate, and $\mathrm{NH}_{3} \mathrm{~N}$ (Table 4). Age had a significant effect on IVOMD disappearance $(P=0.023)$ and butyrate $(P=0.002)$, valerate $(P<0.0001)$, and ammonia nitrogen $(P=0.009)$ concentrations. The lowest values for IVOMD $(45.8 \%)$, valerate $(0.69 \mathrm{mM})$, and $\mathrm{NH}_{3} \mathrm{~N}$ $\left(10.8 \mathrm{mg} \cdot 100 \mathrm{~mL}^{-1}\right)$ were observed for age class I, indicating a trend of increasing values with increasing plant age. With the exception of age class IV, butyrate concentration trended generally higher as plant age increased. For each of these 
Table 2. Basin sagebrush individual volatile fatty acid (VFA) and total VFA simple effect means by age class (I-IV) ${ }^{1}$ and fermentation time (24 h or $48 \mathrm{~h})$, for growing season nutritional characteristics in Wyoming, 1998.

\begin{tabular}{|c|c|c|c|c|c|c|c|c|}
\hline & \multicolumn{2}{|c|}{ I } & \multicolumn{2}{|c|}{ II } & \multicolumn{2}{|c|}{ III } & \multicolumn{2}{|c|}{ IV } \\
\hline & 24 & 48 & 24 & 48 & 24 & 48 & 24 & 48 \\
\hline Acetate, ${ }^{2}$ molar $\%$ & $77.82 a^{3}$ & $69.11 \mathrm{~b}$ & $73.65 \mathrm{a}$ & $70.36 \mathrm{~b}$ & $73.23 \mathrm{a}$ & $69.54 \mathrm{~b}$ & $71.33 \mathrm{a}$ & $68.74 \mathrm{~b}$ \\
\hline Propionate ${ }^{2}$ molar $\%$ & $13.20 \mathrm{C}$ & $21.39 \mathrm{a}$ & $18.45 \mathrm{~b}$ & $20.38 \mathrm{a}$ & $18.88 \mathrm{~b}$ & $21.11 \mathrm{a}$ & $17.83 \mathrm{~b}$ & $19.90 \mathrm{a}$ \\
\hline Buturate, $^{2}$ molar $\%$ & 0.00 & 0.00 & 0.04 & 0.37 & 0.06 & 0.39 & 3.01 & 3.02 \\
\hline Isovalerate, ${ }^{2}$ molar $\%$ & 0.00 & 0.52 & 0.00 & 0.41 & 0.00 & 0.53 & 0.02 & 0.27 \\
\hline Total VFA, ${ }^{2} \mathrm{mM}$ & $50.30 \mathrm{C}$ & $64.0 \mathrm{~b}$ & $55.18 \mathrm{~b}$ & $60.25 \mathrm{~b}$ & $52.34 \mathrm{C}$ & $70.0 \mathrm{a}$ & $52.15 \mathrm{C}$ & $60.01 \mathrm{~b}$ \\
\hline
\end{tabular}

1I includes 1-10 yr; II, 11-20 yr; III, 21-30 yr; IV, 31-40 yr.

${ }^{2}$ Standard errors ranged from 0.03 to 1.52 .

${ }^{3}$ Rows means with different letters differ at $P<0.05$.

parameters, values were higher for the 48 -h fermentation period.

Age class by time interactions were indicated for acetate, propionate, isobutyrate, isovalerate, and total VFA. No clear age effect trends were discernable (Table 5). Although not statistically evaluated, the 48 -h fermentation time provided higher values than the $24-\mathrm{h}$ time period for acetate, propionate, and total VFA.

\section{Subspecies Comparison}

No interactions between subspecies and fermentation times were observed for IVDMD, IVOMD, total VFA, and $\mathrm{NH}_{3} \mathrm{~N}$. Therefore, we conducted a one-way analysis of variance to investigate potential differences among sagebrush subspecies for IVDMD, IVOMD, total VFA, and $\mathrm{NH}_{3} \mathrm{~N}$ during a 48-h fermentation period. CP, NDF, ADF, and ADL components were also compared among sagebrush subspecies (Table 6). Mountain sagebrush had significantly lower IVOMD $(44.1 \%)$ and total VFA concentration $(37.1 \pm 1.6 \mathrm{mM})$ than basin $(48.8 \%$, $58.04 \pm 1.1 \mathrm{mM})$ or Wyoming $(47.9 \%, 59.6 \pm 3.6 \mathrm{mM})$ subspecies $(P<0.0001)$. $\mathrm{NH}_{3} \mathrm{~N}$ concentration was greatest for basin sagebrush $(17.98 \mathrm{mM} ; P<0.0001)$. Although not statistically different $(P=0.08)$, Wyoming sagebrush had slightly more $\mathrm{NH}_{3} \mathrm{~N}$ content $\left(13.29 \mathrm{mg} \cdot 100 \mathrm{~mL}^{-1}\right)$ than mountain sagebrush (11.45 mg $\left.100 \mathrm{~mL}^{-1}\right)$. Wyoming sagebrush also had higher fractions of NDF, ADF, and ADL than both basin and mountain subspecies $(P<0.0001)$. Basin sagebrush had higher $\mathrm{CP}$ content than the other two subspecies $(P=0.0001)$ and higher NDF content $(P<0.0001)$ than mountain sagebrush. Overall, mountain sagebrush had lower values in all categories than the other two subspecies.

\section{DISCUSSION}

Plant age had no effect on IVDMD for basin and Wyoming subspecies, but decreased with increasing age for mountain sagebrush. IVOMD decreased with increasing age for basin and mountain, but increased for Wyoming sagebrush. However, the magnitude of difference in each case was only a few percentage points (even though statistically significant).

$\mathrm{NH}_{3} \mathrm{~N}$ concentration for basin sagebrush decreased with increasing age exhibiting a three-unit decrease between age classes II and IV. For Wyoming sagebrush, $\mathrm{NH}_{3} \mathrm{~N}$ increased with increasing age, rising about $3 \%$ between age classes I and IV. Mountain sagebrush exhibited no age trend. The pooled average of all age classes $\left(17.98 \mathrm{mg} \cdot 100 \mathrm{~mL}^{-1}\right)$ for $\mathrm{NH}_{3} \mathrm{~N}$ is slightly lower than the minimum level $\left(20 \mathrm{mg} \cdot 100 \mathrm{~mL}^{-1}\right)$ required for uninhibited rumen fermentation activity (Preston 1986b).

Table 3. Mountain sagebrush percent in vitro dry matter disappearance (IVDMD), in vitro organic matter disappearance (IVOMD), individual volatile fatty acid (VFA), total VFA, and ammonia nitrogen $\left(\mathrm{NH}_{3} \mathrm{~N}\right)$ concentration main effect means by age class and fermentation time, for growing season nutritional characteristics in Wyoming, 1998.

\begin{tabular}{|c|c|c|c|c|c|c|c|c|c|c|c|}
\hline & \multicolumn{8}{|c|}{ Age class $^{1}$} & \multicolumn{3}{|c|}{ Time } \\
\hline & I & II & III & IV & V & VI & VII & SE & $24 \mathrm{~h}$ & $48 \mathrm{~h}$ & SE \\
\hline$\%$ IVDMD & $49.1 a b^{2}$ & $50.4 \mathrm{a}$ & $48.6 a b c$ & $49.3 a b$ & $47.2 \mathrm{bc}$ & 47.9 bc & $46.4 \mathrm{C}$ & 0.8 & $45.0 \mathrm{~b}$ & $51.8 \mathrm{a}$ & 0.4 \\
\hline$\%$ IVOMD & $44.8 \mathrm{ab}$ & $45.8 \mathrm{a}$ & $44.3 a b c$ & $45.4 \mathrm{a}$ & $42.9 \mathrm{bc}$ & $43.7 \mathrm{abc}$ & $42.2 \mathrm{c}$ & 0.9 & $40.6 \mathrm{~b}$ & $47.7 \mathrm{a}$ & 0.4 \\
\hline Acetate, molar \% & 62.67 & 58.85 & 64.47 & 76.65 & 66.80 & 79.56 & 82.04 & 6.70 & 65.17 & 75.30 & 3.6 \\
\hline Propionate, molar \% & 16.96 & 17.52 & 18.35 & 19.91 & 21.05 & 18.14 & 21.48 & 1.05 & $17.71 \mathrm{~b}$ & $20.40 \mathrm{a}$ & 0.56 \\
\hline Butyrate, molar \% & 8.39 & 10.23 & 9.94 & 9.23 & 10.75 & 9.78 & 10.63 & 0.86 & $10.64 \mathrm{a}$ & $9.05 \mathrm{~b}$ & 0.46 \\
\hline Isobutyrate, molar \% & 5.25 & 6.09 & 5.21 & 0.03 & 0.08 & 0.10 & 0.08 & 0.30 & 2.54 & 2.27 & 0.16 \\
\hline Valerate, molar \% & 1.23 & 1.13 & 1.09 & 1.28 & 1.45 & 1.34 & 1.47 & 0.19 & 1.20 & 1.36 & 0.07 \\
\hline Isovalerate, molar \% & 0.05 & 0.05 & 0.05 & 0.20 & 0.00 & 0.00 & 0.00 & 0.01 & 0.03 & 0.02 & 0.003 \\
\hline Total VFA, mM & $40.60 \mathrm{a}$ & $39.21 \mathrm{a}$ & $43.43 \mathrm{a}$ & $39.12 \mathrm{a}$ & $30.98 \mathrm{~b}$ & $36.70 a b$ & $29.35 b$ & 3.44 & $32.84 \mathrm{~b}$ & $41.27 \mathrm{a}$ & 1.61 \\
\hline $\mathrm{NH}_{3} \mathrm{~N}, \mathrm{mg} \cdot 100 \mathrm{~mL}^{-1}$ & 12.03 & 11.54 & 11.05 & 10.63 & 11.33 & 10.78 & 11.33 & 0.74 & 11.39 & 11.55 & 0.36 \\
\hline
\end{tabular}

${ }^{1} \mathrm{I}$ includes 1-10 yr; II, 11-20 yr; III, 21-30 yr; IV, 31-40 yr; V, 41-50 yr; VI, 51-60 yr; VII, > 60 yr.

${ }^{2}$ Row means with different letters differ at $P<0.05$. 
Table 4. Wyoming sagebrush percent in vitro dry matter disappearance (IVDMD), in vitro organic matter disappearance (IVOMD), individual volatile fatty acid, and ammonia nitrogen $\left(\mathrm{NH}_{3} \mathrm{~N}\right)$ concentration main effect means by age class and fermentation time, for growing season nutritional characteristics in Wyoming, 1998.

\begin{tabular}{|c|c|c|c|c|c|c|c|c|c|c|}
\hline & \multicolumn{7}{|c|}{ Age class $^{1}$} & \multicolumn{3}{|c|}{ Time } \\
\hline & I & II & III & IV & V & VI & SE & $24 \mathrm{~h}$ & $48 \mathrm{~h}$ & SE \\
\hline$\%$ IVDMD & 50.6 & 50.5 & 53.1 & 51.9 & 52.4 & 52.5 & 1.2 & $46.4 \mathrm{a}$ & $57.3 \mathrm{a}$ & 0.4 \\
\hline$\%$ IVOMD & $45.8 a^{2}$ & $46.6 a b$ & $49.7 \mathrm{a}$ & $48.1 \mathrm{a}$ & $48.6 \mathrm{a}$ & $49.0 \mathrm{a}$ & 1.4 & $41.9 \mathrm{~b}$ & $54.0 \mathrm{a}$ & 0.5 \\
\hline Butyrate, molar \% & $6.07 \mathrm{a}$ & $6.28 \mathrm{a}$ & $6.51 \mathrm{a}$ & $4.46 \mathrm{~b}$ & $6.44 \mathrm{a}$ & $6.25 \mathrm{a}$ & 0.54 & 5.72 & 6.27 & 0.31 \\
\hline Valerate, molar \% & $1.63 \mathrm{~b}$ & $1.75 \mathrm{~b}$ & $1.19 b$ & $2.22 \mathrm{a}$ & $2.00 \mathrm{a}$ & $2.08 \mathrm{a}$ & 0.24 & $2.13 \mathrm{a}$ & $1.73 b$ & 0.14 \\
\hline $\mathrm{NH}_{3} \mathrm{~N} \mathrm{mg} \cdot 100 \mathrm{~mL}^{-1}$ & $10.77 \mathrm{c}$ & $14.54 a b$ & $13.81 \mathrm{abc}$ & $11.95 b c$ & $13.83 a b$ & $14.82 \mathrm{a}$ & 1.51 & $10.06 \mathrm{~b}$ & $16.51 \mathrm{a}$ & 0.57 \\
\hline
\end{tabular}

${ }^{1} \mathrm{I}$ includes 1-10 yr; II, 11-20 yr; III, 21-30 yr; IV, 31-40 yr; V, 41-50 yr; VI, > $50 \mathrm{yr}$.

${ }^{2}$ Row means with different letters differ at $P<0.05$.

Fermentation product levels were low for the three subspecies despite relatively high CP and NDF contents. We hypothesize this is likely due to the abundance of terpenoid compounds in sagebrush plant tissue. Striby et al. (1987) reported that terpenoids may act as a digestibility reducing agent and form relatively indigestible complexes with plant protein, leading to reduced assimilation rates of dietary nitrogen, inhibition of microbial digestive enzymes, and microbial activity in the rumen. This is important because cellulose digestibility and fiber fractions increase when $\mathrm{NH}_{3} \mathrm{~N}$ levels rise above $20 \mathrm{mg} \cdot 100 \mathrm{~mL}^{-1}$ (Preston 1986a). All observed $\mathrm{NH}_{3} \mathrm{~N}$ concentrations were well below this $20 \mathrm{mg} \cdot 100 \mathrm{~mL}^{-1}$ threshold. Secondary metabolic products are suspected of influencing sagebrush palatability, digestibility, and intake by browsing animals (Nagy 1979; Welch and McArthur 1979; Welch and Pederson 1981; Kelsey et al. 1982; Personius et al. 1987).

All subspecies in all age classes provided lower amounts of propionate than the desired level of $25-30 \%$ for ruminants proposed by Preston (1986b). Mountain sagebrush content of propionate was generally low compared to the other two subspecies, which may necessitate additional forage glucose sources for effective microbial activities. Previous research (Hemsley and Moir 1963; Slyter et al. 1971) indicated readily fermentable carbohydrates, such as starch, modified the rumen microbe population to satisfy the strict growth requirements of cellulotic microorganisms. If sagebrush is used as a new alternative forage source in the summer by cattle, they may require supplementation. Wild ruminants may also have a negative nutritional status in some winters due to sagebrush forage characteristics and lack of additional forages.
As anticipated, the 48-h fermentation period generally produced greater values than the 24-h period (Tilly and Terry 1963; Nelson et al. 1975). Fermentation products and disappearances for the 48 -h period were higher in 64 of 70 instances. In the four instances where this was not the case, values were very low and likely indicate no biological significance.

Basin sagebrush had a higher CP fraction than the other two subspecies, confirming the results of Welch and McArthur (1979), demonstrating that basin sagebrush consistently has higher CP levels than both mountain and Wyoming subspecies. Mountain sagebrush had the lowest IVOMD and lower total VFA, NDF, and ADL fractions than the other two subspecies. Mountain sagebrush also had a statistically lower ADF fraction than Wyoming sagebrush and a nonstatistically lower CP fraction.

For all three subspecies, total VFA content was dominated by acetate. Soluble carbohydrate components of forages, especially simple sugars, are rapidly metabolized in the rumen and result in a propionate-dominant fermentation. At the other extreme, structural carbohydrates (e.g., cellulose and hemicellulose) are fermented more slowly, resulting in acetate-dominant fermentation. Increased soluble carbohydrate (e.g., starch and sugar) content results in an increased relative content of propionate that subsequently leads to an increased incorporation of rumen ammonia into microbial protein (Dove and Milne 1994). Their report also indicated that a higher acetate-propionate ratio may reduce the efficiency of metabolizable energy utilization and rumen microbe production. Corbett (1987) suggested that when this ratio exceeds $3: 1$, the supply of readily available energy can be regarded as limiting for microbial protein

Table 5. Wyoming sagebrush individual volatile fatty acids (VFAs), and total VFA concentration simple effect means by age class (I-VI) ${ }^{1}$ and fermentation time (24 h or $48 \mathrm{~h}$ ), for growing season nutritional characteristics in Wyoming, 1998.

\begin{tabular}{|c|c|c|c|c|c|c|c|c|c|c|c|c|}
\hline & \multicolumn{2}{|c|}{ I } & \multicolumn{2}{|c|}{ II } & \multicolumn{2}{|c|}{ III } & \multicolumn{2}{|c|}{ IV } & \multicolumn{2}{|c|}{ V } & \multicolumn{2}{|c|}{$\mathrm{VI}$} \\
\hline & $24 \mathrm{~h}$ & $48 \mathrm{~h}$ & $24 \mathrm{~h}$ & $48 \mathrm{~h}$ & $24 \mathrm{~h}$ & $48 \mathrm{~h}$ & $24 \mathrm{~h}$ & $48 \mathrm{~h}$ & $24 \mathrm{~h}$ & $48 \mathrm{~h}$ & $24 \mathrm{~h}$ & $48 \mathrm{~h}$ \\
\hline Acetate, ${ }^{2}$ molar $\%$ & $74.40 a^{3}$ & $71.23 \mathrm{bc}$ & $76.07 \mathrm{e}$ & $71.23 \mathrm{bc}$ & $76.60 \mathrm{~d}$ & $72.40 \mathrm{a}$ & $82.04 \mathrm{a}$ & $69.01 \mathrm{c}$ & $73.02 \mathrm{~b}$ & $69.40 \mathrm{~b}$ & $71.05 \mathrm{C}$ & $68.62 \mathrm{bc}$ \\
\hline Proprionate, ${ }^{2}$ molar $\%$ & $17.75 \mathrm{~b}$ & $21.62 \mathrm{c}$ & $15.50 \mathrm{c}$ & $20.05 \mathrm{C}$ & $14.63 \mathrm{C}$ & $19.13 \mathrm{a}$ & $10.73 d$ & $22.84 \mathrm{~b}$ & $19.02 \mathrm{a}$ & $21.70 \mathrm{a}$ & $20.47 \mathrm{a}$ & $22.28 \mathrm{a}$ \\
\hline Isobutyrate, ${ }^{2}$ molar \% & $0.00 \mathrm{~b}$ & $0.00 \mathrm{~b}$ & $0.32 \mathrm{~b}$ & $0.06 \mathrm{~b}$ & $0.11 \mathrm{~b}$ & $0.06 \mathrm{~b}$ & $1.09 \mathrm{a}$ & $0.00 \mathrm{~b}$ & $0.00 \mathrm{~b}$ & $0.00 \mathrm{~b}$ & $0.00 \mathrm{~b}$ & $0.00 \mathrm{~b}$ \\
\hline Isovalerate, ${ }^{2}$ molar $\%$ & $0.31 \mathrm{bc}$ & $0.16 \mathrm{c}$ & $0.10 \mathrm{~cd}$ & $0.33 \mathrm{~b}$ & $0.14 \mathrm{~cd}$ & $0.48 \mathrm{a}$ & $0.74 \mathrm{a}$ & $0.35 \mathrm{~b}$ & $0.00 \mathrm{~d}$ & $0.35 \mathrm{~b}$ & $0.19 \mathrm{~cd}$ & $0.62 \mathrm{a}$ \\
\hline Total VFA, ${ }^{2} \mathrm{mM}$ & $57.23 \mathrm{a}$ & $62.16 \mathrm{c}$ & $41.16 \mathrm{c}$ & $66.87 \mathrm{~b}$ & $43.93 \mathrm{C}$ & $79.89 \mathrm{a}$ & $51.34 \mathrm{~b}$ & $63.44 \mathrm{bc}$ & $57.05 \mathrm{a}$ & $69.77 a b$ & $53.01 \mathrm{~b}$ & $69.31 \mathrm{ab}$ \\
\hline
\end{tabular}

${ }^{1} \mathrm{I}$ includes 1-10 yr; II, 11-20 yr; III, 21-30 yr; IV, 31-40 yr; V, 41-50 yr; VI, >50 yr.

${ }^{2}$ Standard errors ranged from 0.12 to 6.41 .

${ }^{3}$ Row means with different letters within fermentation time categories differ at $P<0.05$. 
Table 6. Big sagebrush subspecies means and standard errors (SE) for in vitro dry matter disappearance (IVDMD), in vitro organic matter disappearance (IVOMD), total volatile fatty acid (VFA) molar \% and ammonia nitrogen $\left(\mathrm{NH}_{3} \mathrm{~N}\right)$ concentration, and percent crude protein (CP), neutral detergent fiber (NDF), acid detergent fiber (ADF), and acid detergent lignin (ADL), for growing season nutritional characteristics in Wyoming, 1998.

\begin{tabular}{lcccc}
\hline & & Subspecies & & \\
\cline { 2 - 4 }$\%$ IVDMD & Basin & Wyoming & Mountain & 2.4 \\
$\%$ IVOMD & $53.1 \mathrm{a}^{1}$ & $51.5 \mathrm{a}$ & $48.4 \mathrm{~b}$ & 0.8 \\
Total VFA, mM & $48.8 \mathrm{a}$ & $47.9 \mathrm{a}$ & $44.1 \mathrm{~b}$ & 3.66 \\
$\mathrm{NH}_{3} \mathrm{~N}, \mathrm{mg} \cdot 100 \mathrm{~mL}^{-1}$ & $58.04 \mathrm{a}$ & $59.60 \mathrm{a}$ & $37.06 \mathrm{~b}$ & 0.64 \\
$\mathrm{CP} \%$ & $17.98 \mathrm{a}$ & $13.29 \mathrm{~b}$ & $11.45 \mathrm{~b}$ & 0.3 \\
$\mathrm{NDF} \%$ & $12.8 \mathrm{a}$ & $9.8 \mathrm{~b}$ & $9.3 \mathrm{~b}$ & 0.5 \\
ADF \% & $41.3 \mathrm{~b}$ & $45.8 \mathrm{a}$ & $36.8 \mathrm{c}$ & 0.9 \\
ADL \% & $28.9 \mathrm{~b}$ & $32.8 \mathrm{a}$ & $28.2 \mathrm{~b}$ & 0.2 \\
\hline
\end{tabular}

${ }^{1}$ Row means with different letters differ $(P<0.05)$.

synthesis. All sagebrush subspecies in this study yielded high acetate-propionate ratios ranging from 3.3 to 4.6:1, suggesting supplementation with a soluble carbohydrate source or ensuring concurrent availability of green forage may be beneficial for domestic animals foraging heavily on sagebrush (Dziba et al. 2007).

Overall, this research questions a common, anecdotal contention that older sagebrush plants contain less nutritional value than younger ones, at least for growing season conditions. Although age effects (decreasing content with increasing age) seem to be slightly more consistent for mountain sagebrush, consistent with Wambolt (2004), the age effects observed in this study probably have little biological or ecological significance since most parameter differences were very small and below livestock requirements. Research must now focus on plant agenutritional content characteristics under winter conditions, a time when many wild and domestic animals have a greater reliance on sagebrush as a forage. During winter, ephemeral leaves and reproductive shoots are no longer part of the available forage of sagebrush plants. This may alter forage quality during the winter period when only mature, perennial leaves and woody stems are available to the foraging animal. Instances where animals show foraging preference for younger sagebrush plants may have more to do with terpene-plant age content dynamics or landscape position than age-related nutritional content. Age effects on terpene concentrations have not been investigated, and may inhibit intake regardless of nutritional content. Our study looked at age effects within mature sagebrush stands. Younger sagebrush plants growing in other types of landscape positions such as burned-over or fire rehabilitation areas may provide different results.

\section{MANAGEMENT IMPLICATIONS}

Growing season nutritional content of big sagebrush subspecies occurring in mature stands in Wyoming is not appreciably affected by age. Nutrition is generally not a limiting factor during the growing season for most wild animal species of sagebrush habitats. Even if a substantial fraction of summer diet is composed of big sagebrush, other forages will be available for wild ruminants to supplement deficient requirements. Manipulating domestic ruminants to consume a larger portion of sagebrush in their summer diets may, however, require supplementation to maintain satisfactory production levels. Manipulation of sagebrush habitats to foster younger age plants has little relevance for growing season nutritional content. Winter quality and terpene content, however, may or may not respond to plant age in the same fashion.

\section{LITERATURE CITED}

Association of Official Analytical Chemists. 2000. Official methods of analysis. 18th ed. Revision 2. Gaithersburg, MD, USA: AOAC.

Beetle, A. A. 1960. A study of sagebrush, the section Tridentatae of Artemisia. Wyoming Agricultural Experiment Station Bulletin No. 368. Laramie, WY, USA: Wyoming Agricultural Experiment Station. 83 p.

Bonham, C. D., T. R. Cottrell, and J. F. Mitchell. 1991. Inferences for life history strategies of Artemisia tridentate subspecies. Journal of Vegetation Science 2:339-344.

Chaney, A. L., and E. P. Marbach. 1962. Modified reagents for determination of urea and ammonia. Clinical Chemistry 8:130-132.

Corbett, J. L. 1987. Energy and protein utilization by grazing animals. In: L. Wheeler, C. Pearson, and G. Robards [EDs.]. Temperate pastures. Melbourne, Australia: Australian Wool Cooperation/CSIRO. p. 341-355.

Dove, H., and J. A. Milne. 1994. Digesta flow and rumen microbial protein production in ewes grazing perennial ryegrass. Australian Journal of Agriculture Research 45:1229-1245.

Dziba, L. E., F. D. Provenza, J. J. Villalba, and S. B. Atwood. 2007. Supplemental energy and protein increase use of sagebrush by sheep. Small Ruminant Research 69:203-207.

Erwin, E. S., G. J. Macro, and E. M. Emery. 1961. Volatile fatty acids analysis of blood and rumen fluid by gas chromatography. Journal of Dairy Science 44:1768.

Ferguson, C. W. 1964. Annual rings in big sagebrush. Papers of the Laboratory of Tree-Ring Research No. 1. Tucson, AZ, USA: The University of Arizona Press. $95 \mathrm{p}$.

Hemsley, J. A., And R. J. Moir. 1963. The influence of higher volatile fatty acids on intake of urea supplemented low quality cereal hay by sheep. Australian Journal of Agricultural Research 14:509-517.

Jeracl, J. L., T. Hernandez, J. B. Robinson, and P. J. Van Soest. 1988. New and improved procedure for neutral detergent fiber [abstract]. Journal of Animal Science 66(Suppl 1):351.

Kelsey, R. G., J. R. Stephens, and F. Shafizadah. 1982. The chemical constituents of sagebrush foliage and their isolation. Journal of Range Management 35:617-622.

Maier, A. M., B. L. Perryman, R. A. Olson, and A. L. Hild. 2001. Climatic influences on recruitment of 3 subspecies of Artemisia tridentata. Journal of Range Management 54:699-703. 
McDougall, R. I. 1948. Study on ruminant saliva: the composition and output of sheep saliva. Bio-Chemistry Journal 43:99.

MilleR, R. F., T. J. SveCAR, And N. E. West. 1994. Implications of livestock grazing in the intermountain sagebrush region: plant composition. In: M. Vavra, W. Laycock, and R. Pieper [EDS.]. Ecological implications of livestock herbivory in the west. Denver, CO, USA: Society for Range Management. p. 101-146.

Montana Department of Fish, Wildife, and Parks. 1991. Sagebrush bulletin. Available at: http://fwp.mt.gov/insidefwp/fwplibrary/sagebrushbulletin.asp. Accessed 8 June 2009.

Nagy, J. G. 1979. Wildlife nutrition and the sagebrush ecosystem. In: G. F. Gifford, F. E. Busby, and J. P. Shaw [EDS.]. The sagebrush ecosystem: a symposium; April 1978; Logan, UT, USA. Logan, UT, USA: College of Natural Resources, Utah Agricultural Experiment Station. p. 164-168.

Nelson, B. D., C. R. Montgomery, P. E. Schilling, and L. Mason. 1975. Effects of fermentation time on in vivo relationships. Journal of Dairy Science 59:270-277.

Perryman, B. L., A. M. Maler, A. L. Hild, and R. A. Olson. 2001. Demographic characteristics of Artemisia tridentata Nutt. subspecies. Journal of Range Management 54:166-170.

Perryman, B. L., and R. A. Olson. 2000. Age-stem diameter relationships of big sagebrush and their management implications. Journal of Range Management 53:342-346

Personius, T. L., C. L. Wambolt, J. R. Stephens, and R. G. Kelsey. 1987. Crude terpenoid influence on mule deer preference for sagebrush. Journal of Range Management 40:84-88.

Pieper, R. D. 1994. Ecological implications of livestock grazing. In: M. Vavra, W. Laycock, and R. Pieper [EDS.]. Ecological implications of livestock herbivory in the west. Denver, CO, USA: Society for Range Management. p. 177-211.

Preston, T. R. 1986a. Guidelines on establishing feeding system for ruminants, FA0. Animal Production and Health Paper No. 50/2. Rome, Italy: Food and Agriculture Organization of the United Nations. p. 5-52.

Preston, T. R. 1986b. Analytical methods for characterizing feed resources for ruminants, FAO. Animal Production and Health Paper No. 50/2. Rome, Italy: Food and Agriculture Organization of the United Nations. p. 80-125.
Riggs, R. A., S. C. Bunting, and S. E. Daniels. 1996. Prescribed fire. In: P. Krausman [ED.]. Rangeland wildlife. Denver, CO, USA: Society for Range Management. p. 295-319.

SAS. 2008. Statistical Analysis Software JMP version 7.0.2. Cary, NC, USA: SAS Institute Inc.

Slyter, L. L., D. L. Kern, J. M. Weaver, R. R. Oltuen, and R. L. Wilson. 1971. Influence of starch and nitrogen sources on ruminal microorganisms of steers fed high fiber purified diets. Journal of Nutrition 101:847-853.

Steel, R. G. D., J. H. Torrie, and D. A. Dickey. 1996. Principles and procedures of statistics: a biometrical approach. 3rd ed. New York, NY, USA: McGraw-Hill Book Co. 672 p.

Striby, K. D., C. L. Wambolt, R. G. Kelsey, and K. M. Havstad. 1987. Crude terpenoid influence on in vitro digestibility of sagebrush. Journal of Range Management 40:244-248

Tilley, J. M. A., And R. A. TerRy. 1963. A two stage technique for the in vitro digestion of forage crops. Journal of British Grassland Society 18:104.

TuelleR, P. T. 1979. Food habits and nutrition of mule deer on Nevada ranges. Reno, NV, USA: University of Nevada-Reno, Nevada Agricultural Experiment Station Publication R128. 104 p.

Wambolt, C. L. 2004. Browsing and plant age relationships to winter protein and fiber of big sagebrush subspecies. Journal of Range Management 57:620623.

Welch, B. L. 1989. Nutritive value of shrubs. In: C. McKell [ed.]. The biology and utilization of shrubs. San Diego, CA, USA: Academic Press. p. 405-424.

Welch, B. L., and E. D. McArthur. 1979. Variation in winter levels of crude protein among Artemisia tridentata subspecies grown in a uniform garden. Journal of Range Management 32:467-468.

Welch, B. L., And J. C. Pederson. 1981. In vitro digestibility among accessions of big sagebrush by wild mule deer and its relationship to monoterpenoid content. Journal of Range Management 34:497-500.

Wyoming Water Resources Data System. 2007. National Weather Service Climate Station Data. Laramie, WY, USA: Wyoming Water Resources Center, University of Wyoming. 